\title{
Calcific tendinitis of flexor carpi ulnaris: an easy misdiagnosis
}

W. G. RYAN

Department of Orthopaedic Surgery, Withington Hospital, Nell Lane, Manchester

SUMMARY

Calcific tendinitis in the wrist is rare, and frequently misdiagnosed. A case is described and discussed with a review of the literature.

\section{CASE HISTORY}

A 47-year-old lady, whose normal job in a factory had recently been changed, sustained several minor blows to the wrist in the course of her work.

She developed pain in the right wrist over the course of 1 day, which was so severe that she presented to the accident and emergency (A\&E) department. Clinically there was extreme tenderness over the volar aspect of the right ulnar styloid, and active wrist flexion was painful. Radiographs (Fig. 1) showed calcification in the tissues adjacent to the right ulnar styloid, corresponding to the flexor carpi ulnaris tendon.

It was thought by the A\&E Senior House Officer that there was a fracture of the ulnar styloid, and the patient was treated in a plaster cast, and referred to the fracture clinic.

When reviewed, the orthopaedic surgeon made the correct diagnosis of calcific tendinitis of the flexor carpi ulnaris. The patient's symptom had improved slightly and she required a short period in a resting splint until there was full symptomatic relief.

\section{DISCUSSION}

Acute calcification in the hand was first described by Cohen in 1924, and sporadic reports have appeared since.

Correspondence: W. G. Ryan, Department of Orthopaedic Surgery, Withington Hospital, Nell Lane, Manchester M20 8LR, U.K. 


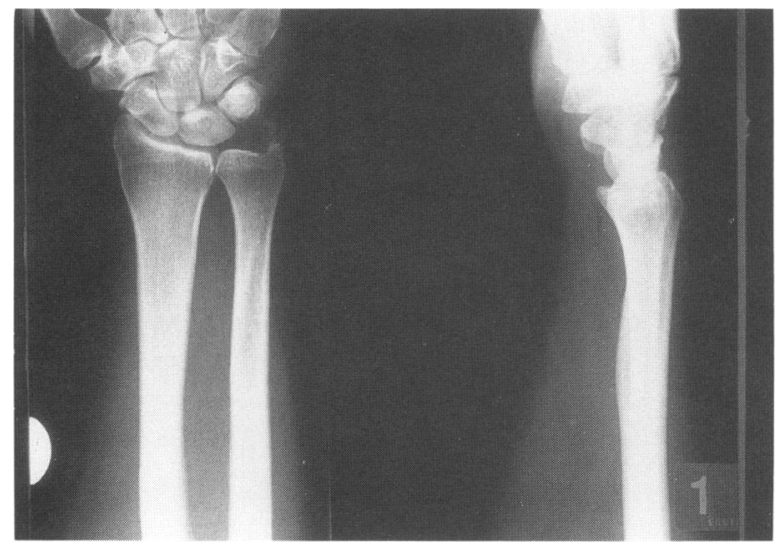

Fig. 1. Radiograph showing calcification in the tissues adjacent to the right ulnar styloid.

Carroll et al. (1955) reported 100 cases but there have been only nine reported cases in the literature of recent years (Greene \& Louis, 1980; Colavita et al., 1983; Selby, 1984; Shaw, 1986; Dilley \& Tonkin, 1991). Six of these were misdiagnosed as avulsion fractures, extra ossicles, gout, arthritis and infection.

Carroll et al. (1955), who operated on some of his patients, found calcific deposits in the tendons. These were calcium phosphate and oxalate, whereas Selby (1984) reported the presence of hydroxyapatite crystals.

Two theories of calcium deposition have been proposed. Carroll suggests 'local stress necrosis' as a cause, whilst Uhthoff et al. (1976) suggested local hypoxia due to mechanical or vascular changes, may be the cause. This would lead to transformation of tendon to fibrocartilage, and, through chondrocyte activity, produce calcification. Subsequent vascular proliferation brought about resorption by macrophages.

The natural history of the disease is resolution, which can be aided by resting in a splint, which is symptomatically helpful. The patient described returned to her asymptomatic state after 20 days, and her problem did not recur.

An increased awareness of this condition should allow accurate diagnosis and appropriate management.

\section{REFERENCES}

Carroll R. E., Sinton W. \& Garcia A. (1955) Acute calcium deposits in the hand. Journal of The American Medical Association 157(5), 422-426.

Cohen I. (1924) Calcareous deposit at the insertion of flexor carpi ulnaris tendon following trauma. American Journal of Surgery 38, 172-173

Colavita N., Solivelti F. M., Vecchioli A. \& Bock E. (1983) Peritendinitis calcarea of flexor carpi ulnaris. Diagnostic Imaging 52, 284-286.

Dilley D. F. \& Tonkin M. A. (1991) Acute calcific tendinitis in the hand and wrist. Journal of Hand Surgery 16B, 215-216. 
Greene T. L. \& Louis T. S. (1980) Calcifying tendinitis in the hand. Annals of Emergency Medicine 9(8), $438-440$.

Selby C. L. (1984) Acute calcific tendinitis of the hand: an infrequently recognised and frequently misdiagnosed form of periarthritis. Arthritis and Rheumatism 27(3), 337-340.

Shaw J. A. (1986) Acute calcific tendonitis in the hand. Orthopaedic Revieze 15(7), 482-485.

Uhthoff H. K., Sarkar K. \& Maynari J. A. (1976) Calcifying tendinitis. A new concept of its pathogenesis. Clinical Orthopaedics and Related Research 118, 164-168. 